\title{
Management of Character Education at SMA Negeri 1 Semendawai Barat
}

\author{
Dewi Aturida ${ }^{1 *}$, Bukman Lian ${ }^{2}$, Alhadi Yan Putra ${ }^{2}$ \\ ${ }^{1}$ SMAN 1 Semendawai \\ ${ }^{2}$ Universitas PGRI Palembang \\ *Corresponding author. Email: dewiaturidadewi@gmail.com
}

\begin{abstract}
The study aims to describe the management of character education at SMA Negeri 1 Semendawai Barat. This research used a qualitative approach. An Observation, interviews, and documentation as data collection techniques. We analyze data using reduction, data presentation, and verification (conclusion). We found that the implementation of character education in SMA Negeri 1 Semendawai Barat is carried out in an integrated manner through three main channels: integrated within learning activities, extracurricular, and cultural and habituation activities. The results showed the character education management at SMA Negeri 1 Semendawai Barat had gone well. It is planned to be guided by the school's vision and mission and involves all elements in the school, well organized, implemented properly and dynamically, and controlled and supervised by the authorities through the school supervision program.
\end{abstract}

Keywords: Management, Character Education, Senior High School

\section{INTRODUCTION}

Character degradation caused by not developing good character occurs a lot among students. It can be seen with students cheating on exams, frequent brawls between students, entangled in drug cases, involved in promiscuity, low level of care for others, good courtesy began to be abandoned, and there was less respect for parents. The existence of motorcycle gangs and student gangs often disturbed the community and even led to criminal acts such as murder, bullying, assault and rape. These behaviors clearly show quite severe degradation, one of which is caused by not optimal development of character education in educational institutions and unsupportive environmental conditions [1]. This apprehensive condition is a big challenge for the government, educational institutions, teachers, and parents to further improve character education for students, both character education developed in the family, school, and community environment [2].

Various alternatives have been proposed to overcome character degradation problems, such as regulations, legislation, and increased efforts to implement better laws. The most common alternative to reducing this character problem is education because it is considered a preventive alternative to building generations. Education is an effort to promote character growth (inner strength, character), mind (intellect), and children's bodies. So it is clear, education is the primary vehicle for developing good character [3].

The government's concern about character education is stated in Permendikbud Number 20 of 2018 concerning the Program for the Strengthening of Character Education (PPK). An educational policy whose main purpose to implement Nawacita in the national education system. This PPK policy is integrated into the National Movement for the Mental Revolution (GNRM), a change in ways of thinking, behaving and acting for the better. The main values of PPK are religious, nationalist, independent, mutual cooperation, integrity. The values instilled and practiced through the national education system are known, understood, and applied in all aspects of life in schools and in society [4].

Character education is placed as a foundation for realizing the vision of national development, namely "realizing a society with noble, moral, ethical, cultured and civilized character based on the philosophy of Pancasila" [4]. Although it is not new, character education is a major issue in the world of education. Character education is expected to equip students with 
basic abilities that are able to make life-long learners one of the important characters to live in an era of globalization and be able to function with participation. positive ones both as individuals, as family members, as citizens, and as citizens of the world [5].

Based on pre-research through interviews and observations conducted at SMA Negeri 1 Semendawai Barat, implementing 2013 curriculum learning integrates character education in each subject through extracurricular activities and teaching and learning activities. Strengthening character education that is implemented at this school. Students must be at school before 7:15 a.m. After that hour, the gate is closed by a security guard. Students who are late get sanctions/coaching. The principal of SMA Negeri 1 Semendawai Barat stated that there had been no cases of student delinquency in the last five years, such as drugs, theft, harassment, brawls, motorbike gangs, and others the police have handled. This shows that there is a strong commitment from the school to developing character education in its schools.

\section{METHODS}

We used a qualitative approach and descriptive method. In this study, we collect data about the management of character education at SMA Negeri 1 Semendawai Barat OKU Timur, including planning, organizing, implementing and supervising character education. We collect the data using observation, interviews, and documentation techniques.

We use observations on the management of character education in the school. We designed the observation-like checklist design., if there is data that is not in the checklist, the data will be recorded in the field. We utilize observation aids such as a video camera, establish operational definitions, establish clear parameters, involve more complementary observations, and ensure that the subject being observed does not know that he is being observed.

The things that need to be observed in this study include, the key informants in this study who are companions of Islamic spiritual activities. The principal as a key informant is based on researchers' observations of the process of activities carried out routinely as well as in-depth knowledge of Islamic spiritual activities. Meanwhile, the student as a Supporting Informant 1 has responsibility for the process of Islamic spiritual activities. Vice principal of Curriculum as Supporting Informant 2 has responsibility as an educator manager who facilitates students in the process of teaching and learning activities.

We used semi-structured interviews that consist of a list of questions that were questions about Character Education. If there were things the researcher felt were less in-depth during the interview, the researcher could use more in-depth information. We determine the informants to be interviewed. Then we conduct interviews with informants according to the research needs. Overcoming problems during interviews. Researchers used a data recorder in the form of field note sheets and cellphones as a tool for photos. After completing the interview, the researcher recorded in the field notebook and analyzed the interview results and sorted out the data obtained. Besides, we use documentation that has long been used in research as a data source that can be used to test, interpret, and even to enliven [6].

Data analysis in character education management research is carried out before we enter the field, during data collection, and after completing data collection within a certain period. The research data analysis conducted is intended to answer the problem formulation regarding character education management. Following this, data analysis is carried out interactively through data collection processes, data reduction, data display, and conclusions drawing/verifying [7].

\section{RESULTS AND DISCUSSION}

\section{a. Character Education Planning}

Planning is an activity to set goals or objectives to be achieved. Learning planning is a rational document arranged systematically about student development with the aim of making learning more effective and efficient. Planning basically determines the activities to be carried out in the future [8]. Because with the planning of the education process it will run according to what is expected.

Success in planning requires the active role of all stakeholders in realizing the mission of the school. Their involvement must be pursued from the start, namely from the formulation of a character education program that is integrated in the school program, so that they are involved in analyzing school conditions, formulating expectations involved in the implementation of school programs [8] [9].

The involvement and role of school members in planning character education for school, Mr. Suyanto explained as follows: "Planning is made at the beginning of the school year in the preparation of the Education Unit Level Curriculum (KTSP) to discuss the school program for the next year. In the preparation of the KTSP involved many parties, namely: the principal, the vice principal in the curriculum field, the deputy principal for student affairs, the deputy principal in the field of infrastructure, the deputy principal in the field of public relations, the entire teacher board, the school committee, the supervisor of the supervisor. Participate in the form of providing input for the realization of the vision and mission of the school" 
Character education program adjusted to the vision, mission, and goals of SMA Negeri 1 Semendawai Barat was expressed by Mr. Suyanto, as follows: "In making a character education program that is integrated in the school curriculum aims to realize the vision, mission, of the school and in accordance with the goals of national education"

Regarding the strategy carried out so that each component developed in the school program has clear corridors, and each component in the school has the same perception and synergizes in realizing the vision, mission and goals of the school which is a mutual agreement by all elements of education, Mr. Suyanto explained as follows: "Character education is an integrated curriculum program, so in KTSP SMA Negeri 1 Semendawai Barat has integrated character education”.

Every program that is structured to run well needs support from all school members, including parents and the community. School residents must understand various things related to character education programs, parents, and the community because they are the main supporters of the success or failure of character education. The duties of parents provide sufficient motivation and space to develop children's potential according to the maximum developmental stages. In this case, Suyanto explained that: Schools conduct character education socialization. Socialization aims to equalize perceptions about the concept of character education [10].

Character education programs are socialized to school members, parents and the community [11]. Based on the documentation result, socialization to school residents through flag ceremony activities. Socialization to teachers and employees through regular monthly and semester meetings, while socialization to parents and the community is carried out during school committee meetings and also at the distribution of report cards at the end of the semester.

The strategy for implementing character education to be carried out well, the principal stated that: Character education at SMA Negeri 1 Semendawai Barat is implemented in activities carried out at SMA Negeri 1 Semendawai Barat, both learning and learning activities, extracurricular activities, and habituation activities that are routinely carried out at school.

From this plan, character education planning can be identified through the types of activities that the school has planned in one year including:

\section{Planning for character education in learning}

Learning planning is the initial stage that a teacher must go through in teaching preparation to be able to present a quality learning process. Good lesson planning can improve learning outcomes and increase student motivation in carrying out learning. One form of teaching preparation is by compiling a Lesson Plan (RPP) and providing the learning media needed to support the learning process.

Based on the results of interviews that we conducted with several teachers, it was found that the teacher always made a lesson plan before carrying out learning activities in the classroom. In addition, the teacher also prepares material and media that will be used in the implementation of learning so that the learning process can run optimally.

The characters planned by the teacher are listed in the syllabus and lesson plans, as raised by the informants during interviews like this: Character values that are expected to grow in students are listed in the syllabus and lesson plans, according to the direction of the principal and what kind of curriculum field when early year meeting, where character values must be grown in the learning process [12].

Planning for character education in extracurricular activities

Extracurricular activities designed by the school must match the needs and potentials of the school. Planning for extracurricular activities includes needs analysis, planning for funds and facilities, benefits for students and schools and determining strategies. The strategy used at SMA Negeri 1 Semendawai Barat in planning the extracurricular implementation program is conveyed by the principal as follows: "The extracurricular that is carried out at school is in accordance with the conditions of the capacity of the facilities and infrastructure as well as the extracurricular coaches in the school environment and also the readiness of the existing budget funds. Then the school will determine what extracurricular activities the school can $d o "$

Based on observations, there are several types of extracurricular activities in SMA Negeri 1 Semendawai Barat, including: Scout extracurricular activities that all students must participate in, extracurricular for Youth Scientific Work (KIR), extracurricular Islamic spirituality (Rohis), Extracurricular Sports, Extracurricular Line Training (LTBB), extracurricular arts in the form of dance studios, extracurricular English clubs.

Character Education Planning in Cultural and Habitual Activities

Cultural activities and habituation in fostering character educators in students include; Routine habit, Spontaneous habituation, and Modeling habits. 
Routine activities are activities carried out by students continuously and consistently according to the existing schedule. In this case Nani Febriyanti as the student representative stated that: "Some of the habituation activities carried out are daily in nature, some weekly. Daily activities include: tidiness, daily class pickets, and also praying together in the morning. While the weekly activities are: ceremony every Monday, exercise every Saturday, clean Friday"

Based on the interview above and the results of observations of the character education program at SMA Negeri 1 Semendawai Barat, it is made in the form of daily routine activities and weekly routine activities.

Spontaneous refraction is an attitude that is carried out spontaneously which arises from seeing the conditions that exist around us. Character education is not formed instantly but must be trained seriously and proportionally through spontaneous activities and habituation [13].

Based on the results of observations of character building activities in students at SMA Negeri 1 Semendawai Barat that are spontaneous, including: $3 \mathrm{~S}$ movements (smile, greetings, greetings) that have been cultivated at school, throwing garbage in its place, queuing culture, overcoming disagreements.

The attitudes and behavior of the teachers are real examples and role models of students in developing character education. Therefore, it is hoped that the teachers and employees will be able to behave well. Mr. Suyanto stated in his interview: "Teachers are always required to be a model and a real example for their students both in discipline, neatness in dress, speaking polite words, working hard. With hope that the teachers can become role models for their students"

Based on the results of the interview, it was revealed that SMA Negeri 1 Semendawai Barat planned the absence of teachers and employees in fostering good character for students by providing examples of attitudes and behavior so that later they could become role models for students and students by watching them.

\section{b. Organizing Character Education}

Organizing is the division or arrangement, distributing work, authority to achieve desired goals [14]. School organizing is usually in the form of a division of tasks for educators and education personnel which is carried out at the beginning of the school year.

The organization at SMA Negeri 1 Semendawai barat was carried out at the beginning of the school academic year to hold an early year meeting which was attended by all teachers and staff of SMA Negeri 1 Semendawai Barat. What was discussed at this meeting was the division of tasks for teaching and learning activities, division of duties for leadership staff, division of homeroom teachers, division of extracurricular duties for students, and determining the school calendar to make it easier to arrange existing agendas at school. During the meeting of teachers and employees of SMA Negeri 1 Semendawai Barat, they were given the opportunity to convey opinions, ideas, and also ideas related to character education so that at the beginning of the teaching and learning activities, all parties were ready to carry out their duties according to their respective main duties and functions.

\section{Division of Teacher Tasks}

The division of teacher duties in learning activities is based on educational qualifications according to the diploma held by the teacher. Teachers who are given assignments according to their knowledge qualifications are expected to be able to master the targeted competencies (material) and also be able to present an attractive learning atmosphere in the classroom so as to create students who know, realize / care about, and internalize the values and values. make it a behavior. In this case Mr. Suyanto said that:

"The division of teacher duties is based on educational qualifications, professionalism, and also school needs but at SMA NI Semendawai Barat there are still some teachers who teach subjects that are not appropriate/linear with education, especially for GTT teachers, this is due to the lack of civil servant teachers, while for civil servant teachers have all taught according to their educational qualifications"

The division of the duties of educators in extracurricular tutors

Teachers are needed to guide and coach extracurricular activities to make extracurricular activities run well. Supervising teachers are teachers who the principal gives trust and responsibility to guide and direct and foster students so that extracurricular activities run well and do not interfere with academic activities.

Concrete steps in planning character education at SMA Negeri 1 Semendawai Barat are the socialization of policies on the importance of character education to all school members such as teachers, employees, and students, socialization to parents, and the community. Socialization is carried out at the beginning of the school year to all parties so that the character education offered can be accepted and understood, and implemented optimally and responsibly. Socialization is one of the determinants of the success of character education at SMA Negeri 1 Semendawai Barat.

Character education at SMA Negeri 1 Semendawai Barat is implemented in an integrated manner through three main channels, namely: Integrated 
in learning activities, Integrated through extracurricular activities, and Integrated through cultural and habituation activities.

Planning for character education at SMA Negeri 1 Semendawai Barat is poured into planning character education in learning, planning for character education in extracurricular activities, planning for character education in cultural and habituation activities.

The implementation of Character Education is integrated in three activities, namely: integrated into intracurricular/learning activities, integrated into extracurricular activities, habituation at school [13].

\section{Implementation of character education in learning}

The implementation of learning in the context of cultivating character education can be carried out with various methods, approaches that allow students to be active in learning activities and to get to know and apply character values in everyday life.

The implementation of character education in learning at SMA Negeri 1 Semendawai Barat is in accordance with the regulation of the minister of education and culture number 81a 2013 attachment IV concerning the implementation of the curriculum which states that the learning process consists of five main learning experiences, namely observing, asking, gathering information, associating and communicating (Ministry of Education, 2010: 36)

The learning characteristics of SMA Negeri 1 Semendawai Barat are carried out with learning activities that are centered on students, by presenting learning activities that are effective, creative, innovative and fun as well as educating. The teacher acts as a facilitator to guide and direct students in learning activities.

\section{Implementation of character education in extracurricular activities}

Based on the results of observations and interviews in the field, researchers can conclude that the implementation of character education in extracurricular activities at SMA Negeri 1 Semendawai Barat is in accordance with the guidelines for implementing character education of the Ministry of Education and Culture which states that extracurricular activities are part of student development and is included in the education quality improvement group [14].

\section{Implementation of character education in habituation and cultural activities.}

The habituation and culture of character values in schools, especially outside the classroom, are the teachers' responsibility as educators. The involvement of all stakeholders in the school is very much needed in habituation and acculturation activities. The principal must be a role model for all school members about instilling character values. The habituation and acculturation activities at school are carried out through routine activities, spontaneous activities, and exemplary conditioning [14].

Routine activities carried out at SMA Negeri 1 Semendawai barat include flag ceremony activities, morning exercises every Saturday, group prayers, clean Saturdays, recitation every Friday, class pickets and office pickets. Spontaneous activities carried out at SMA Negeri 1 Semendawai barat include getting used to saying greetings and shaking hands to teachers, employees and fellow students, getting used to being polite, getting used to throwing garbage in its place, getting in line, getting used to respecting other people's opinions, getting used to asking permission when going out into the classroom or room, getting used to helping or helping others.

\section{CONCLUSION}

Based on the results, we conclude that:

a. Planning for character education at school through the following stages: determining the character values you want to develop in school, compiling a school work program at the beginning of the school year, compiling the goals of school, document character education programs in integrated into the education unit level curriculum (KTSP) of SMA Negeri 1 Semendawai Barat in document I, socializing the character education program to all school members, parents of students and the community.

b. Organizing the character education of SMA Negeri 1 Semendawai, among others, through organizing the division of teaching tasks based on the scope of the work of the teacher, job descriptions, meeting face-to-face hours, the distribution of coaches for extracurricular activities, and assigning character education activities for the habituation and coaching process

c. The implementation of character education management at SMA Negeri 1 Semendawai Barat is integrated through 3 things, namely: (1) integrated in learning activities, it is hoped that students will master learning material also have character values, (2) integrated implementation of character education in extracurricular activities is expected to be able fostering the interest and talent of students as well as instilling character values, (3) integrated implementation of habituation and culture activities to create an atmosphere or character climate through routine activities, spontaneous activities and exemplary activities as well as conditioning. 
d. Supervision of supervisory activities is carried out by the principal as the leader which is carried out through supervision activities, extracurricular guidance teacher reports, and the achievement of character development is given in academic assessments on student report cards.

Based on the results, we give suggestion to school especially for Senior high school:

a. Schools should conduct socialization and motivation to school members by inviting experts on character education

b. Schools need to collaborate and communicate with parents / guardians and all related agencies to continue improving character education in schools.

c. Schools need to increase supervision of the implementation of character education by increasing supervision instruments in implementing learning that includes character education and supervision of extracurricular activities and habituation and cultural activities in schools.

\section{REFERENCES}

[1] Kesuma, D. (2011). Pendidikan karakter: kajian teori dan praktik di sekolah. PT Remaja Rosdakarya.

[2] Azmi, N. (2017). Manajemen Pendidikan Karakter Siswa Man 1 Brebes dan MAN 2 Brebes (Doctoral dissertation, IAIN Purwokerto).

[3] Kementrian Pendidikan Nasional. (2010). Pendidikan Karakter, Teori dan Aplikasi. Jakarta : Dirjen Dikdasmen.

[4] Kementrian Pendidikan Nasional. (2010). Kerangka Acuan Pendidikan Karakter. Jakarta

[5] Lian, B \& Sarina. (2018). Pengembangan Pendidikan Kewirausahaan Berbasis Pendidikan Karakter di SMA Negeri 1 Tanjung Raja. Jurnal Manajemen,Kepemimpinan dan Suvervisi Pendidikan. Volume 3 No 2. Hal 191-199.

[6] Moleong, L. J. (2017). Metode Penelitian Kualitatif. Remaja Rosdakarya: Bandung

[7] Sugiyono. (2013). Metode Penelitian Kualitatif dan Kuantitatif. Alfabeta: Bandung

[8] Susanti, S., Lian, B., \& Puspita, Y. (2020). Implementasi Strategi Kepala Sekolah dalam Penguatan Pendidikan Karakter Peserta Didik. Jurnal Pendidikan Tambusai,4(2), 1644-1657.

[9] Gunawan, H. (2012). Pendidikan Karakter Konsep dan Implementasi. Bandung : Alfabeta.
[10] Kementrian Pendidikan Nasional. (2011). Panduan Pelaksanaan Pendidikan Karakter. Jakarta : Pusat Kurikulum

[11] Kementrian Pendidikan Nasional. (2010). Bahan Pelatihan Pengembangan Pendidikan Budaya dan Karakter Bangsa. Jakarta : Pusat Kurikulum

[12] Lickona, Tom, Eric Schaps, \& Catherine Lewis. (2012). CEP's Eleven Principles of Effective Character Education." Character Education Partnership.

[13] Kompri. (2015). Manajemen Pendidikan 1. Bandung: Alfabeta.

[14] Gunawan, I. (2012). Mengembangkan Karakter Bangsa Berdasarkan Kearifan Lokal. Paper presented at the Prosiding Seminar Nasional 